\title{
Études/Inuit/Studies
}

BLACKMAN, Margaret B., 2004 Upside Down: Seasons among

the Nunamiut, Lincoln, University of Nebraska Press, 228 pages.

\section{William Schneider}

Volume 30, numéro 1, 2006

Problématiques des sexes

Gender issues

URI : https://id.erudit.org/iderudit/016156ar

DOI : https://doi.org/10.7202/016156ar

Aller au sommaire du numéro

\section{Éditeur(s)}

Association Inuksiutiit Katimajiit Inc.

Centre interuniversitaire d'études et de recherches autochtones (CIÉRA)

ISSN

0701-1008 (imprimé)

1708-5268 (numérique)

Découvrir la revue

Citer ce compte rendu

Schneider, W. (2006). Compte rendu de [BLACKMAN, Margaret B., 2004 Upside Down: Seasons among the Nunamiut, Lincoln, University of Nebraska Press,

228 pages.] Études/Inuit/Studies, 30(1), 183-184. https://doi.org/10.7202/016156ar d'utilisation que vous pouvez consulter en ligne.

https://apropos.erudit.org/fr/usagers/politique-dutilisation/ 


\section{Recensions / Book Reviews}

BLACKMAN, Margaret B.

2004 Upside Down: Seasons among the Nunamiut, Lincoln, University of Nebraska Press, 228 pages.

Upside Down: Seasons among the Nunamiut is a collection of essays written by anthropologist and creative non-fiction writer, Dr. Margaret Blackman. The 26 pieces focus on subjects as diverse as the use of CB radios ("Anaktuvuk Pass, you copy?") to the writings of Simon Paneak and Justus Mekiana, revered elders and leaders whose journals are now links back to the early days in the Brooks Range ("Writing History from the Pass").

Blackman and her family are prominent in all of the essays, sometimes in a very personal way ("Ed's Place"), and in other pieces, in a more background way, such as in "Tulugak Lake and Beyond," the story of a family trip with Mabel Paneak Burris to an old campsite where she grew up. We share in her thrill as she discovers the ancient treasures of her past, leading Blackman's archeologist husband to remark, "Mabel's been collecting her childhood." In "Of meat and hunger and Everlasting Gob stoppers," my favorite in the collection, we are introduced to the local candy merchant with her vast selection of goodies and the steady stream of youngsters, including Blackman's daughter, who make their way to the counter. This description is followed by two stories of starvation recalled by elders but obviously far from the experience of the young who frequent the candy store. The contrast is powerful and riveting.

Blackman is no newcomer to Anaktuvuk Pass. She first visited in 1980, returned in 1988, and has been coming back most summers to visit, conduct research, and write. Her most recent project is the Anaktuvuk Pass masks. "Faces of the Nunamiut" and "The Exhibition" are our introductions to this work.

The title of the book, Upside Down: Seasons among the Nunamiut appears to have several meanings. First, summers are when Blackman does her field work and, unlike winter with its darkness, cold, and scheduled schooling for children, summer is a free time for the young. Kids have few obligations and no schedule. "Upside Down" for Blackman is also the contrast she feels between life as she sees it in Anaktuvuk Pass and life as she lives it back in Brockport, New York where she teaches. I suppose another intended meaning is to point out the contrasts between our expectations of what Eskimo life is like, and the realities of life described in this community today. A little over 50 years ago, today's elders were living a nomadic life without scheduled or predictable access to western goods, health services, and schooling. Now, we are confronted by caribou hunters living in a fully modern village where "The only Road that goes there is the Information Superhighway." Probably this contrast is less startling for the members of the community, but for the reader, it is dramatic. The contrasts are 
artfully drawn by the author who references, but does not dwell, on the past. History percolates up into the discussion and supports the essays giving them depth without overshadowing the focus on life today in the Pass. This is both good writing and solid ethnography.

This book may be one of the best ways to introduce students to anthropology because it gives a first hand look and feel on many aspects of the fieldwork experience in the 21 st century. The tone is respectful, considerate of the villagers' privacy, and it is frank and honest about ups and downs of this type of work.

There are several minor things about the essays that I question, and could easily be rectified in a next edition. The book needs an index so we can easily find reference to people, dates, and events. In several places, Blackman repeats explanations or descriptions from earlier essays; reference to the first mention would provide a graceful connection and remind us of the context under consideration. Some essays are more compelling than others. For instance, "The Things we carry," which chronicles her semester teaching at the University of Alaska Fairbanks, seems distant from the subject, but could provide contrast to the next essay, "Town," which deals with people coming to town from the village, the frenzy of activities, appointments, and shopping. Blackman's semester long trip was for very different reasons and the needs she describes are also quite different from the needs of villagers who come to town. This contrast could make for good comparison, but in its present form, it is more implicit than explicit, by virtue of its placement before "Town" and her reference to the nomadic Nunamiut and what they carried.

Finally, there is "Ed's Place," an explanation and description of how her marriage disintegrated. Could she, should she, have written this differently? Her partnership with her husband is intertwined with their fieldwork and is part of the history of anthropological research in the Pass. As readers, we want to know how and why this partnership dissolved and its impact on the author and her work, but I question the level of detail; it seems intrusive on the lives of other family members whose story is now in print.

\author{
William Schneider \\ Elmer Rasmuson Library \\ University of Alaska Fairbanks \\ Fairbanks 99775-6800 \\ Alaska, USA \\ ffwss@uaf.edu
}

BONNERJEA, René

2004 Eskimos in Europe: How they got there and what happened to them afterwards, London and Budapest, Biro Family Ltd., 470 pages. [Order from rene@bonnerjea.fslife.co.uk.] 